\title{
Influence of low calcium and low pH on melting characteristics of model Raclette cheese ${ }^{t / 2}$
}

\author{
Marie-Therese FröHLich-Wyder* , Dominik Guggisberg, Daniel Wechsler
}

Agroscope Liebefeld-Posieux Research Station ALP, 3003 Bern, Switzerland

Received 10 February 2009 - Revised 6 April 2009 - Accepted 21 April 2009

Published online 23 June 2009

\begin{abstract}
The aim of this study was to demonstrate the influence of calcium (Ca) reduction on model Raclette cheese meltability using different technological and chemical methods. Analysis was carried out on the detailed chemical, textural and rheological properties of six different model Raclette cheeses: control Raclette cheese manufacture (CON); pre-ripening (PRE) of the cheese milk; and addition of either 50 or $25 \mathrm{~g}$ of citric acid to the wash water (CA50 and CA25) and addition of either 70 or $35 \mathrm{~g}$ of lactic acid to the wash water (LA70 and LA35). The compositional analysis of the samples was carried out within the first $24 \mathrm{~h}$ of manufacture and after 14 weeks of ripening. In particular, total calcium, insoluble calcium (Insol Ca), nitrogen fractions and $\mathrm{pH}$ were examined as they were considered important parameters for meltability. Total $\mathrm{Ca}$ and Insol Ca were both remarkably reduced in CA50 and CA25, and were increased in PRE, LA70 and LA35 compared to the CON. The results of this study suggest that citric acid in the wash water lowered the $\mathrm{pH}$ value of the Raclette cheese and chelated $\mathrm{Ca}$ from the colloidal calcium phosphate, but also changed the rheologically determined melting properties. Various parameters of the small amplitude oscillatory shear test as well as the increase in the force in the compression test and the elevated softening and dropping points all indicated a firmer texture of the CA50 and CA25 cheeses. However, the sensory data for CA50 revealed good "viscous", "ropy" and "gummy" properties of the melted cheese. The apparent discrepancy between the sensory sensation and the rheological data seems to be related to changes in the water-binding capacity of the protein matrix.
\end{abstract}

\section{Raclette cheese / melting / pH / calcium / rheology / sensory property}

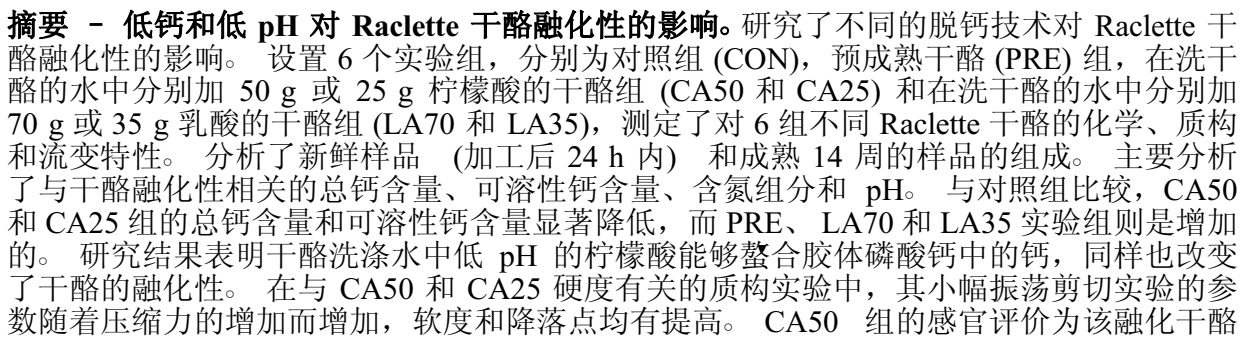

This publication relates to the work presented during the 5th IDF Symposium on Cheese Ripening, 9-13 March 2008, Bern, Switzerland.

*Corresponding author (通讯作者): marie-therese.froehlich@alp.admin.ch 

具有好的“稆性”、“成丝状”和“胶黏性”。造成感官评价与流变学分析的差异可能的原因是
蛋白基质与水结合力不同。

\title{
Raclette 干酪 / 融化性 / pH / 钻 / 流变性 / 感官特性
}

\begin{abstract}
Résumé - Influence d'une faible teneur en calcium et d'un pH bas sur les caractéristiques de fonte d'un fromage à raclette suisse modèle. L'objectif de l'étude était de démontrer l'influence de la diminution de la teneur en calcium sur l'aptitude à la fonte du fromage à raclette suisse en utilisant différents moyens chimiques et technologiques. L'analyse a porté sur les propriétés chimiques, texturales et rhéologiques de 6 fromages à raclette suisse différents : fromage à raclette de fabrication témoin $(\mathrm{CON})$, fromage fabriqué après prématuration du lait (PRE), fromage fabriqué avec ajout de $50 \mathrm{~g}$ ou $25 \mathrm{~g}$ d'acide citrique à l'eau de lavage (CA50 et CA25), ajout de $70 \mathrm{~g}$ ou $35 \mathrm{~g}$ d'acide lactique à l'eau de lavage (LA70 et LA35). L'analyse de la composition des échantillons a été effectuée dans les 24 premières heures de fabrication et après 14 semaines d'affinage. En particulier, la teneur en calcium total $(\mathrm{Ca})$, en calcium insoluble (Insol $\mathrm{Ca}$ ), la fraction azotée et le $\mathrm{pH}$, considérés comme des paramètres importants dans l'aptitude à la fonte, ont été mesurés. Les teneurs en $\mathrm{Ca}$ et Insol Ca diminuaient considérablement dans CA50 et CA25, et augmentaient dans PRE, LA70 et LA35 par rapport au témoin CON. Les résultats de cette étude suggèrent que l'acide citrique dans l'eau de lavage abaissait le $\mathrm{pH}$ du fromage à raclette et chélatait le calcium provenant du phosphate de calcium colloïdal (CCP), mais diminuait aussi l'aptitude à la fonte déterminée par rhéologie. Divers paramètres du test de cisaillement oscillatoire à faible amplitude ainsi que l'augmentation de la force de compression et les valeurs élevées des points de ramollissement et de goutte indiquaient une texture plus ferme pour les fromages CA50 et CA25. Cependant, les données sensorielles pour CA50 révélaient de bonnes propriétés pour les attributs « visqueux ", " filant » et " élastique » des fromages fondus. La divergence apparente entre la perception sensorielle et les données rhéologiques semble liée aux changements dans la capacité de liaison de l'eau de la matrice protéique.
\end{abstract}

raclette / fonte / pH / calcium / rhéologie / propriétés sensorielles

\section{INTRODUCTION}

Swiss Raclette cheese, the most important semi-hard cheese of Switzerland, is mainly consumed in the melted form. Racler in French means to scrape off the melted cheese. The consumption of melted Swiss Raclette cheese is widely popular and therefore its meltability is one of its most important functional properties. Heating causes the cheese to melt and to release fat, and the original structure is altered during the complex melting process. Melted fat may coalesce and result in the separation of fat from the protein matrix. This causes the undesirable effect of oiling off or fat leakage. The re-solidification of fat during cooling may bring about less homogeneous distribution of fat and a significant alteration in the cheese structure [13]. Above $40{ }^{\circ} \mathrm{C}$, milk fat is entirely liquid [36] and factors such as the solubilization of proteins are likely to govern the thermal softening of the cheese.

Every cheese maker has the ambition to manufacture a product with good melting properties within a relatively short ripening period (12-14 weeks) by applying appropriate technologies for the reduction in calcium content during cheese making or for the acceleration of proteolysis during ripening. Actually, it is the interaction of several factors that have a major impact on the melting properties of Swiss Raclette cheese. Proteolysis was long believed to be the most important factor influencing the meltability of Swiss Raclette cheese [5, 38]. Generally, it can be said that long-chain peptides tend to lead to a highly viscous melt, whereas 
short-chain peptides that have a higher water-binding capacity lead to a melt of rather low viscosity. However, for a cheese maker it is not easy to influence this factor. A higher water content is often associated with accelerated ripening and enhanced melting properties [5, 38], but it is not possible to arbitrarily increase the water content because the quality of the cheese may suffer. In contrast, a strong acidification resulting in a low $\mathrm{pH}$ decelerates proteolysis but favours the solubilization and the loss of calcium. Schluep and Puhan [40] observed a relationship between $\mathrm{pH}$, insoluble calcium (Insol $\mathrm{Ca}$ ) and the melting properties of Swiss Raclette cheese. Similarly, various studies conducted by the Agroscope Liebefeld-Posieux Research Station (ALP) confirmed that the total $\mathrm{Ca}$ content plays an important role in the melting properties of Swiss Raclette cheese [8-10]: lower Ca contents were regularly linked to enhanced melting properties.

It is well recognized that total $\mathrm{Ca}$ content, $\mathrm{pH}$ and proteolysis in Mozzarella and Cheddar cheeses are critical parameters that influence the textural and physical properties of these cheese types $[2,12,22,23$, $27,45]$. But it is difficult to study these parameters independently as they are interrelated: $\mathrm{Ca}$ is lost from the casein particles as the $\mathrm{pH}$ decreases during cheese manufacture [27], and the rate of proteolysis is increased as $\mathrm{Ca}$ is lost from the casein $[20,21,29]$. The resulting lower total $\mathrm{Ca}$ levels generally result in softer cheeses and in an increase in meltability [27]. However, total $\mathrm{Ca}$ content alone is not the most useful predictor of the physical melting properties of cheese, but the $\mathrm{Ca}$ that is still associated with casein, described as Insol $\mathrm{Ca}$ [20].

Furthermore, reducing $\mathrm{Ca}$ content by using direct acidification for making a non-fat Mozzarella cheese increases hydration of the protein matrix, leading to a softer cheese and a better melt [30]. The authors observed that $\mathrm{Ca}$ content controls the func- tionality of Mozzarella cheese at a $\mathrm{pH}$ above 5 . Such cheeses typically have higher moisture contents. Lee et al. [24] concluded from their results that Cheddar with $\mathrm{pH}$ values below 5.0 exhibited markedly different interactions and very low meltability compared with cheese with $\mathrm{pH}$ above 5.0. Also, the study carried out by Joshi et al. [22] revealed a limited benefit of the calciumcontrolling effect: a reduction in $\mathrm{Ca}$ beyond $35 \%$ was not greatly beneficial in improving the melt of Mozzarella cheese. Thus, it seems that the meltability of cheese cannot be improved arbitrarily by reducing the $\mathrm{Ca}$ content or the content of Insol Ca beyond a certain point.

The manufacture of Cheddar and Mozzarella cheese differs greatly from that of a Swiss Raclette cheese. Formerly, melting properties of Swiss Raclette cheese were measured by using the softening and dropping point method $[1,7,39]$. In recent studies, a dynamic small amplitude oscillatory shear test was used that allowed the simultaneous determination of various parameters, such as the elastic modulus $G^{\prime}$, the viscous modulus $G^{\prime \prime}$ and the maximum of the loss tangent $\left(\mathrm{LT}_{\max }\right)$. The storage modulus $G^{\prime}$ is a measure of the energy stored and released per oscillation cycle, which can be used as the index of rigidity or elastic characteristics (and when it decreases, it indicates softening of the cheese). LT indicates the ratio of viscous to elastic properties and is related to the relaxation of bonds in the matrix [26, 34]. LT $_{\max }$ indicates the point of highest bond mobility and is often used as a reliable index of meltability or flowability [37]. Low LT values indicate insufficient time for the relaxing of bonds and insufficient meltability. When $\mathrm{LT}_{\max }$ is not reaching a value of 1 , there is no flow and only a weakening of the structure occurs. Lucey et al. [29] showed that the increase in LT occurs at temperatures above the complete melting point of the milk fat $\left(\approx 40{ }^{\circ} \mathrm{C}\right)$ and, therefore, must be caused by changes in the bonds 
and interactions involving the protein matrix. Similarly, the $G^{\prime}-G^{\prime \prime}$ crossover (transition temperature) was previously considered to be a good indicator of cheese meltability $[28,42]$ and re-solidification. The values of the dynamic moduli $G^{\prime}$ and $G^{\prime \prime}$ are indicators of the numbers and the strength of bonds present in the cheese system. Their decrease during heating indicates a loss of network structure. Flow may occur when the viscous modulus $\left(G^{\prime \prime}\right)$ becomes greater than the elastic modulus $\left(G^{\prime}\right)$. The crossover points are called melting point (SMP) and solidification point (ERP), respectively. The complex viscosity $\left(\eta^{*}\right)$ at the transition points SMP and ERP and during cooling at $60{ }^{\circ} \mathrm{C}$ was calculated by the software.

The aim of this study was to examine the influence of $\mathrm{Ca}$ on the melting properties of Raclette cheese by varying the contents of total and Insol Ca. For these purposes, different technological and chemical variants were chosen, which induce a remarkable $\mathrm{pH}$ reduction in order to extract $\mathrm{Ca}$ from the protein matrix during the manufacture of model Raclette cheese.

\section{MATERIALS AND METHODS}

\subsection{Manufacture of model cheeses}

The Raclette cheeses were produced in the pilot plant of ALP according to the manufacturing protocol shown in Figure 1.

The $\mathrm{pH}$ of the cheeses was measured after $0,1,2,3,4$ and $24 \mathrm{~h}$, and at the end of ripening (14 weeks). Total lactic acid, galactose and water were determined after $24 \mathrm{~h}$. Ca in whey, water, fat, sodium chloride, total nitrogen $(\mathrm{TN})$, water-soluble nitrogen (WSN), $\mathrm{pH} 4.6$ soluble nitrogen (SN 4.6), non-protein nitrogen (NPN), which is the $12 \%$ trichloroacetic acid soluble fraction, total calcium (Ca) and watersoluble calcium (WSCa), as well as the sensory characteristics were determined at the end of ripening (14 weeks).

\subsection{Experimental design}

Five variants and one control with one repetition were produced in the pilot plant of ALP. Thus, a total of six cheeses were produced per day from the same milk. The experimental variants were as follows:

- Pre-ripening of the vat milk followed by pasteurization: the milk was pre-ripened with 5\% Lactococcus lactis 17 (ALP, Switzerland) at $16{ }^{\circ} \mathrm{C}$ for $15 \mathrm{~h}$. Pasteurization in the vat followed, according to the manufacturing shown in Figure 1. The stirring period before scalding was adjusted in order to compensate the faster coagulation and to keep the total time of the manufacturing process constant.

- Addition of $50 \mathrm{~g}$ citric acid (100 g/100 L): the wash water was supplemented with $50 \mathrm{~g}$ of citric acid $\left(\mathrm{C}_{6} \mathrm{H}_{8} \mathrm{O}_{7} \cdot \mathrm{H}_{2} \mathrm{O}\right.$, Dr. Grogg Chemie, Berne, Switzerland). The $\mathrm{pH}$ of the whey was 5.33 .

- Addition of $25 \mathrm{~g}$ citric acid $(50 \mathrm{~g} / 100 \mathrm{~L})$ : the wash water was supplemented with $25 \mathrm{~g}$ of citric acid $\left(\mathrm{C}_{6} \mathrm{H}_{8} \mathrm{O}_{7} \cdot \mathrm{H}_{2} \mathrm{O}\right.$, Dr. Grogg Chemie, Berne, Switzerland). The $\mathrm{pH}$ of the whey was 5.83 .

- Addition of $70 \mathrm{~g}$ of $90 \%$ lactic acid $(140 \mathrm{~g} / 100 \mathrm{~L})$ : the wash water was supplemented with $70 \mathrm{~g}$ of $90 \%$ lactic acid. The $\mathrm{pH}$ of the whey was 5.33 .

- Addition of $35 \mathrm{~g}$ of $90 \%$ lactic acid $(70 \mathrm{~g} / 100 \mathrm{~L})$ : the wash water was supplemented with $35 \mathrm{~g}$ of $90 \%$ lactic acid. The $\mathrm{pH}$ of the whey was 5.83 .

The addition of citric and lactic acids was aimed at achieving the same $\mathrm{pH}$ values in the whey. The addition of lactic acid in place of citric acid was chosen as the lactic acid does not have the chelating properties of citric acid. Thus, the use of the two acids allowed studying the impact of $\mathrm{pH}$ reduction and chelation on the total $\mathrm{Ca}$ and Insol $\mathrm{Ca}$ contents in the cheese.

Table I presents the experimental setup of this study. The control cheese was 


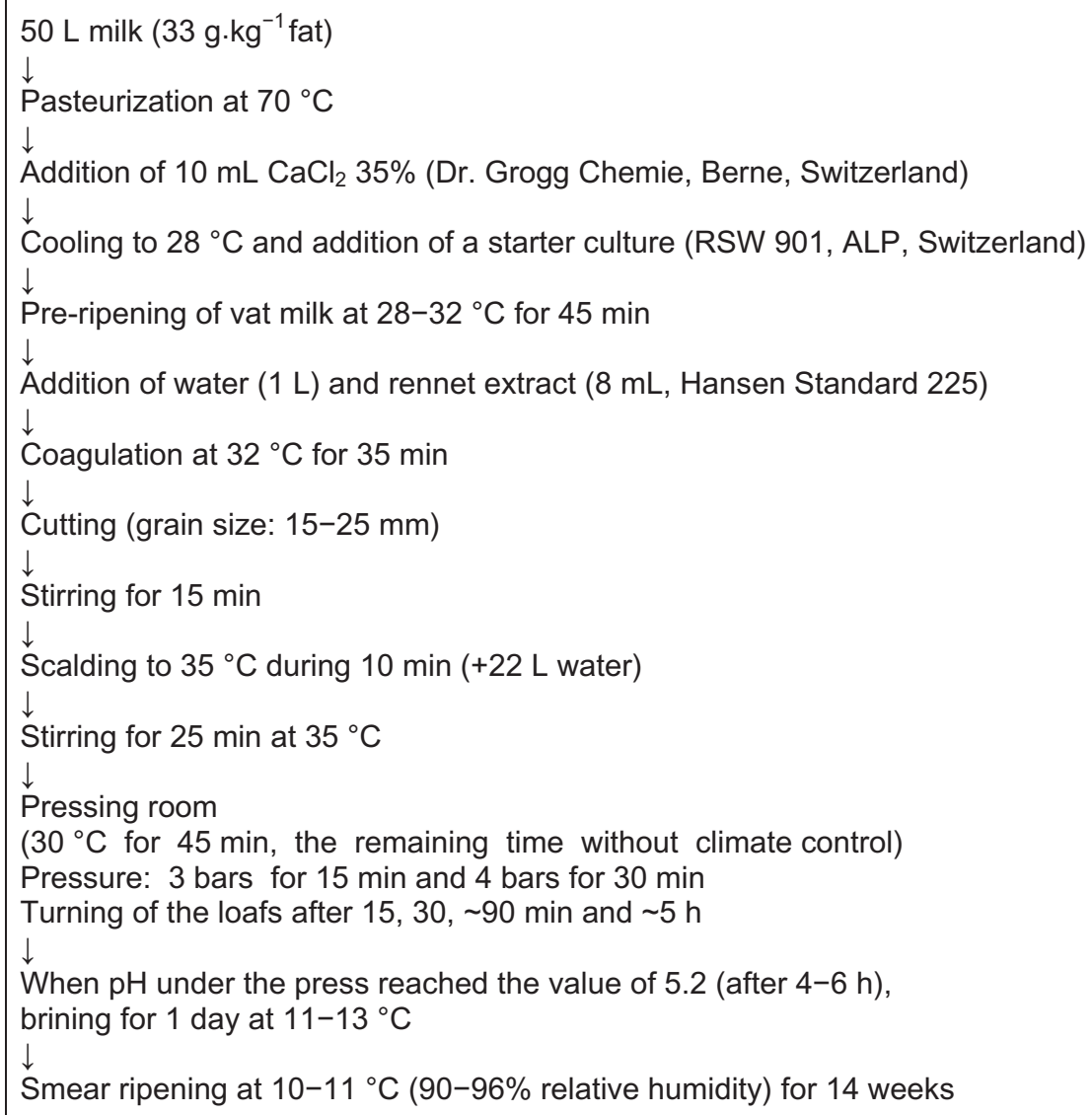

Figure 1. Manufacturing protocol of experimental model Raclette cheese (ALP).

manufactured according to the protocol shown in Figure 1, without overnight preripening of the milk and without additives to the wash water. The additives, added with the wash water to the curd, remained at maximum $35 \mathrm{~min}$ in the curd before pressing.

\subsection{Compositional analysis}

L- and D-Lactic acids and galactose were analysed enzymatically according to the instructions supplied by the kit manufacturer (Roche Diagnostics, Mannheim, Germany).
The water content of cheese was determined by the gravimetric method of the Swiss Food Manual [43] and IDF [14]. Fat in cheese was determined by the Gerber Van Gulik method [18, 19]. Sodium chloride was obtained using the potentiometric titration method [15]. Ca in cheese and in water extract was determined using atomic absorption spectroscopy according to [16]. The water extract for the analyses of soluble $\mathrm{Ca}$ was the same as for the determination of WSN. The content of Insol Ca was calculated from the difference in the contents of total $\mathrm{Ca}$ and soluble $\mathrm{Ca}$. 
Table I. Experimental setup (day 1).

\begin{tabular}{lll}
\hline Vat & \multicolumn{1}{c}{ Variant } & Abbreviation \\
\hline 1 & Control (according to Fig. 1) & CON \\
2 & Pre-ripening of the vat milk & PRE \\
3 & $50 \mathrm{~g}$ citric acid $(100 \mathrm{~g} / 100 \mathrm{~L})$, added with the wash water & CA50 \\
4 & $70 \mathrm{~g}$ lactic acid $90 \%(140 \mathrm{~g} / 100 \mathrm{~L})$, added with the wash water & LA70 \\
5 & $25 \mathrm{~g}$ citric acid $(50 \mathrm{~g} / 100 \mathrm{~L})$, added with the wash water & CA25 \\
6 & $35 \mathrm{~g}$ lactic acid $90 \%(70 \mathrm{~g} / 100 \mathrm{~L})$, added with the wash water & LA35 \\
\hline
\end{tabular}

TN, WSN, SN 4.6 and NPN were determined by the Kjeldahl method with a Vapodest 50 digestion and distillation unit according to $[4,17]$.

\subsection{Sensory analysis}

The sensorial evaluation of the melted Raclette cheeses was performed after heating $(2 \mathrm{~min} 15 \mathrm{~s})$ a slice of cheese $(60 \times$ $60 \times 5 \mathrm{~mm})$ in a commercially available Raclette table oven (Stöckli Cheeseboard V8 1100 W, Stöckli AG, Netstal, Switzerland). The cheese slices were heated each in a small pan at maximum heating position, the temperature reaching $80^{\circ} \mathrm{C}$ in the middle of the melted cheese. The cheese was then scraped on a plate and tested after $30 \mathrm{~s}$ by six experts as described by Fröhlich-Wyder et al. [9]. The temperature in the middle of the melted cheese on the plate reached $60{ }^{\circ} \mathrm{C}$. The following characteristics were tested: "fat separation", "viscosity", "ropy" and "gummy" on a 1-5-point scale, with 5 indicating excellent and 1 insufficient. Good quality of the melted cheese denotes no fat separation, low viscosity, no ropiness and no gumminess.

\subsection{Sample preparation and small amplitude dynamic oscillatory shear testing}

Dynamic oscillatory measurements were performed using a Physica MCR 300
Rheometer (Physica Messtechnik, Stuttgart, Germany) using a profiled parallel plate geometry to avoid "wall slip" (PP25 profiled). The sample preparation and the rheological procedure (frequency: $10 \mathrm{rad} \cdot \mathrm{s}^{-1}$ and maximum shear strain: $0.5 \%$ ) were based on the method developed by Guggisberg et al. [10].

Udayarajan et al. [44] had observed a frequency dependence of the rheological properties, such as the dynamic moduli and LT, when increasing the temperature above $40{ }^{\circ} \mathrm{C}$. In our study, a constant and rather medium frequency of $10 \mathrm{rad} \cdot \mathrm{s}^{-1}$ was used for all the experiments. For this reason, a direct comparison of rheological values with other published data may be difficult.

Changes in viscoelastic properties (storage modulus $G^{\prime}$ and loss modulus $G^{\prime \prime}$ ) were analysed during heating from 20 to $80{ }^{\circ} \mathrm{C}$ and back to $20^{\circ} \mathrm{C}$ were analysed in $60 \mathrm{~min}$.

The following characteristic reference points in the rheogram were evaluated:

- $G^{\prime}$ and $G^{\prime \prime}$ (at $20^{\circ} \mathrm{C}$ ) at the start of the experiment.

- The transition temperature $\left(G^{\prime}-G^{\prime \prime}\right.$ crossover, melting point (SMP) during heating from 20 to $80{ }^{\circ} \mathrm{C}$ ).

- The maximum of the loss tangent $\left(\mathrm{LT}_{\max }\right)$ and the corresponding temperature during heating from 20 to $80{ }^{\circ} \mathrm{C}$.

- Complex viscosity $\left(\eta^{*}\right)$ at the transition temperature during heating.

- $G^{\prime}$ and $G^{\prime \prime}$ (at $80{ }^{\circ} \mathrm{C}$ ). 
- Transition temperature $\left(G^{\prime}-G^{\prime \prime}\right.$ crossover, solidification point (ERP) during cooling from 80 to $20{ }^{\circ} \mathrm{C}$ ).

- Complex viscosity $\left(\eta^{*}\right)$ at the transition temperature during cooling.

- Complex viscosity $\left(\eta^{*}\right)$ at $60{ }^{\circ} \mathrm{C}$ during cooling.

\subsection{Compression test}

The same experiment as described in Section 2.5 was performed with the following modification: when the temperature decreased from 80 to $60{ }^{\circ} \mathrm{C}$, cooling was stopped and a compression test was initiated for $800 \mu \mathrm{m}$ with a constant compression speed of $15 \mu \mathrm{m} \cdot \mathrm{s}^{-1}$. The maximum force was determined.

\subsection{Softening and dropping point method}

The softening (EP) and dropping points (TP) were evaluated using the automatic Mettler-Thermosystem FP 800 system (Mettler-Toledo, Greifensee, Switzerland) according to Eberhard et al. [5, 7].

\subsection{Statistical analysis}

The variance of the response variables was analysed with SYSTAT (Systat for Windows, Version 11.0, Systat Software Inc., San Jose, CA 2004) using general linear model. Once it was determined that the means of the variants were different, a post hoc test was performed in order to find out which variant differed from the control. Since the Dunnett test is only available with one-way designs, a Fisher's LSD test with a Bonferroni adjustment was carried out. For these purposes, the $P$ value from the Fisher's LSD test was multiplied by the number of variants minus one, in our case thus five.

\section{RESULTS AND DISCUSSION}

\subsection{Compositional analyses}

\subsubsection{Analyses within the first $24 \mathrm{~h}$ of cheese manufacture with special emphasis on $\mathrm{pH}$ values}

As expected, the chosen technological and chemical variants were able to induce varying $\mathrm{pH}$ gradients, not only during initial manufacture but also during ripening. Already in the 1-day-old cheeses, there were marked, but not significant, differences between the variants in the cheese trial. The addition of either citric or lactic acid brought about reduced contents of water and lactic acid compared to the control (Tab. II). As intended, the $\mathrm{pH}$ values varied markedly between the variants. Figure 2 shows the differences in the $\mathrm{pH}$ development during manufacture and ripening of the cheeses. CA50 and LA70 had the most drastic effect on $\mathrm{pH}$ reduction, which occurred during the initial manufacture when the supplemented wash water was added. This subsequently led to a comparatively flat $\mathrm{pH}$ gradient with the lowest values both at the beginning $(0 \mathrm{~h})$ and at the end (14 weeks) of ripening, but the highest $\mathrm{pH}$ values after $24 \mathrm{~h}$ compared to the $\mathrm{CON}$ and other variants (Fig. 2). In contrast, the CON cheeses exhibited the highest $\mathrm{pH}$ values both at the beginning $(0 \mathrm{~h})$ and at the end (14 weeks) of cheese ripening, and the lowest values after $24 \mathrm{~h}$. PRE was the only variant with a lowered $\mathrm{pH}$ value before coagulation. This led to a shortening of coagulation time by 15 min and compared to CON cheeses to a lower $\mathrm{pH}$ value at the time of draining.

\subsubsection{Chemical characterization of the model Raclette cheeses after ripening}

After a ripening period of 14 weeks, the water content of the CON cheeses was still 
Table II. Galactose, lactic acid, water and $\mathrm{pH}$ of experimental Raclette cheese after manufacturing (24 h).

\begin{tabular}{lcccc}
\hline $\begin{array}{l}\text { Variant } \\
(n=2)\end{array}$ & $\begin{array}{c}\text { Galactose } \\
\left(\mathrm{mmol} \cdot \mathrm{kg}^{-1}\right)\end{array}$ & $\begin{array}{c}\text { Lactic acid } \\
\left(\mathrm{mmol} \cdot \mathrm{kg}^{-1}\right)\end{array}$ & $\begin{array}{c}\text { Water } \\
\left(\mathrm{g} \cdot \mathrm{kg}^{-1}\right)\end{array}$ & $\mathrm{pH}$ \\
\hline CON & 4.5 & 170.0 & 530.5 & 5.08 \\
PRE & 4.2 & 159.0 & 508.5 & 5.09 \\
CA50 & 4.2 & 136.5 & 500.5 & 5.19 \\
LA70 & 4.0 & 134.5 & $481.5^{*}$ & 5.25 \\
CA25 & 3.7 & 159.5 & 491.5 & 5.11 \\
LA35 & 3.8 & 155.5 & 502.0 & 5.13 \\
$P$ value ANOVA & & & & \\
Variant & n.s. & n.s. & 0.079 & n.s. \\
Day & & n.s. & n.s. & n.s. \\
\hline
\end{tabular}

${ }^{*} P \leq 0.05$; n.s., not significant; asterisks in the same row show significant differences from the control; ANOVA, analysis of variance; day, day of cheese production; CON, control Raclette cheese; PRE, preripening; CA50 and CA25, addition of 50 or $25 \mathrm{~g}$ of citric acid, respectively; and LA70 and LA35, addition of 70 or $35 \mathrm{~g}$ of lactic acid, respectively.

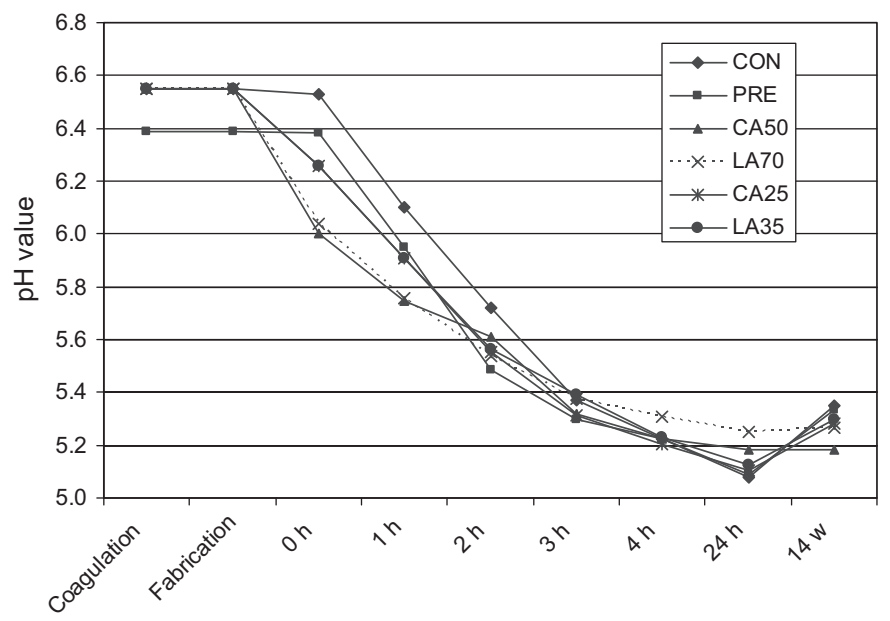

Figure 2. $\mathrm{pH}$ gradients in the experimental Raclette cheeses (mean values, $n=2$ ). CON, control Raclette cheese; PRE, pre-ripening; CA50 and CA25, addition of 50 or $25 \mathrm{~g}$ of citric acid, respectively; and LA70 and LA35, addition of 70 or $35 \mathrm{~g}$ of lactic acid, respectively.

higher than the other variants (Tab. III). However, significant differences were found neither for the fat nor for the sodium chloride content. Only the proportion of nonprotein nitrogen as a percentage of soluble nitrogen at $\mathrm{pH}$ 4.6 (NPN of SN 4.6) presumed an effect of the variants, indicat- ing that LA70 (and probably also CA50) contained a higher proportion of long-chain soluble peptides. This could be a result of enhanced clotting enzyme activity and reduced bacterial peptidase activity due to lower $\mathrm{pH}$ value and water content in the cheese. 
Table III. Chemical composition of experimental Raclette cheese after ripening (14 weeks).

\begin{tabular}{lcccc}
\hline Variant $(n=2)$ & Water $\left(\mathrm{g} \cdot \mathrm{kg}^{-1}\right)$ & Fat $\left(\mathrm{g} \cdot \mathrm{kg}^{-1}\right)$ & $\mathrm{NaCl}\left(\mathrm{g} \cdot \mathrm{kg}^{-1}\right)$ & NPN of SN 4.6 (\%) \\
\hline CON & 493.0 & 245.3 & 28.0 & 76.8 \\
PRE & 468.3 & 254.5 & 27.4 & 75.9 \\
CA50 & 485.3 & 267.0 & 27.0 & 63.6 \\
LA70 & 445.3 & 270.5 & 26.6 & $59.2^{*}$ \\
CA25 & 464.5 & 257.9 & 26.5 & 71.8 \\
LA35 & 467.3 & 259.0 & 26.4 & 68.6 \\
$P$ value ANOVA & & & & $*$ \\
Variant & n.s. & n.s. & n.s. & n.s. \\
Day & n.s. & n.s. & n.s. & \\
\hline
\end{tabular}

${ }^{*} P \leq 0.05$; n.s., not significant; asterisks in the same row show significant differences from the control; ANOVA, analysis of variance; day, day of cheese production; $\mathrm{NaCl}$, sodium chloride; $\mathrm{TN}$, total nitrogen; $\mathrm{SN}$ 4.6, soluble nitrogen at $\mathrm{pH}$ 4.6; NPN, non-protein nitrogen; CON, control Raclette cheese; PRE, preripening; CA50 and CA25, addition of 50 or $25 \mathrm{~g}$ of citric acid, respectively; and LA70 and LA35, addition of 70 or $35 \mathrm{~g}$ of lactic acid, respectively.

In comparison to commercial Swiss Raclette cheeses that usually have a mean water content of $\sim 410 \mathrm{~g} \cdot \mathrm{kg}^{-1}$ [10], the water content of all model Raclette cheeses was considerably higher. Such a divergence will have an influence on the characteristics of the cheese. A higher water content is known to accelerate proteolysis and to have a positive effect on meltability $[6,38]$. Furthermore, a higher residual lactose as a result of the higher water content leads to a greater acidification, and thus, to a greater extraction of $\mathrm{Ca}$ from the protein matrix. As is expected, the $\mathrm{pH}$ with a mean value of 5.3 in the ripe cheeses was lower compared to commercial Swiss Raclette cheeses, where $\mathrm{pH}$ values of 5.6-5.7 are generally found [10]. The model Raclette cheeses, in fact, also revealed lower $\mathrm{Ca}$ contents (Tab. IV) than commercial Swiss Raclette cheeses that generally have a mean total $\mathrm{Ca}$ content of $6.5 \mathrm{~g} \cdot \mathrm{kg}^{-1}$ [10]. In comparison, Cheddar cheese lies in the range of $7-8 \mathrm{~g} \cdot \mathrm{kg}^{-1}$ [24, 29] and Mozzarella cheese in the range of $5.5-6.5 \mathrm{~g} \cdot \mathrm{kg}^{-1}$ [22]. However, for experimental reasons, the same authors produced cheeses with significantly lower Ca contents reaching $5 \mathrm{~g} \cdot \mathrm{kg}^{-1}$ in Cheddar and even $3.5 \mathrm{~g} \cdot \mathrm{kg}^{-1}$ in Mozzarella.

\subsubsection{Investigation of total Ca and Insol Ca contents}

Extraction of Ca was lowest in the CON and PRE cheeses, which was also confirmed by the lower $\mathrm{Ca}$ contents in the whey of the two variants (Tab. IV). The highest Ca loss with whey was obtained with the variants CA50 and LA70. The $\mathrm{pH}$ value at the start of cheese pressing ( $\mathrm{pH}$ at 0 h, Fig. 2) correlated highly significantly with the Ca content of the whey (Fig. 3). A strong $\mathrm{pH}$ reduction during initial manufacture enhances the solubilization of $\mathrm{Ca}$ and leads to a stronger syneresis of the curd that favours the extraction of $\mathrm{Ca}$ from the protein matrix [27]. As expected, CA50 cheeses had the lowest total $\mathrm{Ca}$ content. Surprisingly, the content of total $\mathrm{Ca}$ in the PRE cheeses was even higher than in the $\mathrm{CON}$ cheeses. The weak $\mathrm{pH}$ reduction in the pre-ripened vat milk resulted in a shortening of the coagulation time by $15 \mathrm{~min}$. It is likely that these conditions favoured a stronger syneresis directly after cutting, before a sufficient solubilization of $\mathrm{Ca}$ was achieved, favouring the development of a dense protein matrix with poor $\mathrm{Ca}$ extraction. A similar effect was observed 
Table IV. Calcium contents in whey (24 h) and cheese (14 weeks).

\begin{tabular}{|c|c|c|c|c|c|}
\hline $\begin{array}{l}\text { Variant } \\
(n=2)\end{array}$ & $\begin{array}{l}\text { Ca in whey } \\
\left(\mathrm{mg} \cdot \mathrm{kg}^{-1}\right)\end{array}$ & $\begin{array}{l}\text { Total Ca } \\
\text { in cheese } \\
\left(\mathrm{mg} \cdot \mathrm{kg}^{-1}\right)\end{array}$ & $\begin{array}{c}\text { WSCa } \\
\text { in cheese } \\
\left(\mathrm{mg} \cdot \mathrm{kg}^{-1}\right)\end{array}$ & $\begin{array}{c}\text { Insol Ca } \\
\text { in cheese } \\
(\%)\end{array}$ & $\begin{array}{c}\mathrm{pH} \\
\text { in cheese }\end{array}$ \\
\hline $\mathrm{CON}$ & 311 & 4809 & 3683 & 23.4 & 5.35 \\
\hline PRE & 313 & 5289 & 3744 & 29.1 & 5.34 \\
\hline CA50 & $422^{* *}$ & 3846 & 3420 & 11.1 & 5.18 \\
\hline LA70 & $386^{*}$ & 4884 & 3747 & 23.2 & 5.27 \\
\hline CA25 & 337 & 4653 & 3818 & 17.8 & 5.28 \\
\hline LA35 & 340 & 5104 & 3727 & 26.9 & 5.30 \\
\hline \multicolumn{6}{|c|}{$P$ value ANOVA } \\
\hline Variant & $* *$ & * & n.s. & 0.071 & n.s. \\
\hline Day & n.s. & n.s. & n.s. & n.s. & n.s. \\
\hline
\end{tabular}

${ }^{*} P \leq 0.05 ;{ }^{* *} P \leq 0.01$; n.s., not significant; asterisks in the same row show significant differences from the control; ANOVA, analysis of variance; day, day of cheese production; Ca, calcium; WSCa, water-soluble calcium; Insol, Insoluble; CON, control Raclette cheese; PRE, pre-ripening; CA50 and CA25, addition of 50 or $25 \mathrm{~g}$ of citric acid, respectively; and LA70, LA35, addition of 70 or $35 \mathrm{~g}$ of lactic acid, respectively.

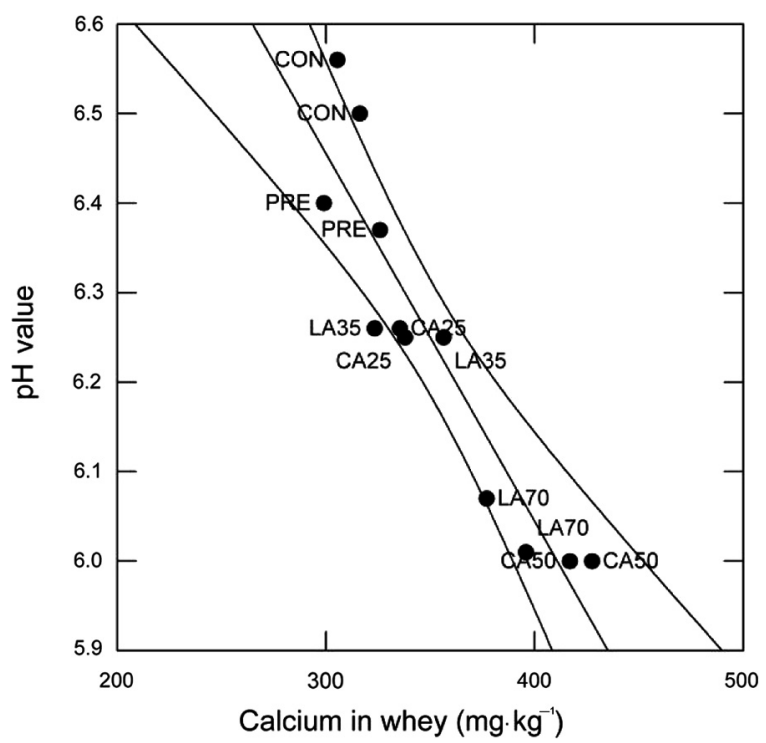

Figure 3. Calcium content and $\mathrm{pH}$ value of whey at the end of manufacture $(R=-0.923$, $P \leq 0.001$, confidence interval on the regression line: 0.95 ). CON, control Raclette cheese; PRE, pre-ripening; CA50 and CA25, addition of 50 or $25 \mathrm{~g}$ of citric acid, respectively; and LA70 and LA35, addition of 70 or $35 \mathrm{~g}$ of lactic acid, respectively.

for the variant LA35 with a weak acidification of the wash water.

Although the variants LA70 and CA50 had comparable $\mathrm{pH}$ values at the end of manufacture and similar $\mathrm{Ca}$ contents in the whey (Fig. 3), they differed considerably in the total $\mathrm{Ca}$ content of the cheese (Tab. IV). While CA50 cheeses showed 


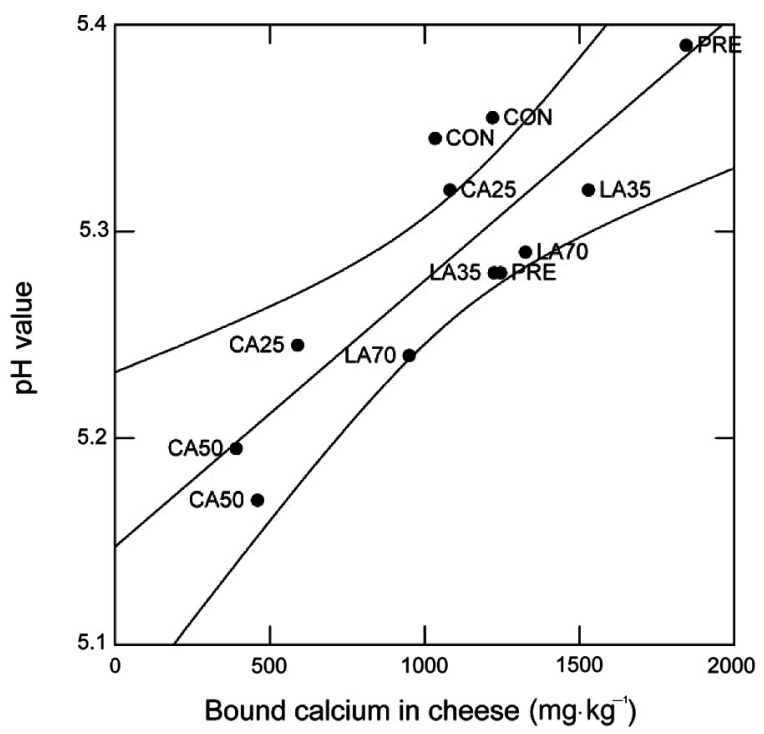

Figure 4. Insoluble calcium content and $\mathrm{pH}$ value in the ripened model Raclette cheeses $(R=0.846, P \leq 0.001$, confidence interval on the regression line: 0.95$)$. CON, control Raclette cheese; PRE, pre-ripening; CA50 and CA25, addition of 50 or $25 \mathrm{~g}$ of citric acid, respectively; and LA70 and LA35, addition of 70 or $35 \mathrm{~g}$ of lactic acid, respectively.

a strong reduction in the total $\mathrm{Ca}$, LA70 cheeses contained almost the same $\mathrm{Ca}$ content as the CON cheeses. This differing behaviour seems to be related to the chelating properties of citric acid sequestering $\mathrm{Ca}$ from the protein matrix and, therefore, decreasing the number of colloidal calcium phosphate (CCP) cross-links [35]. The relatively low content of total $\mathrm{Ca}$ in $\mathrm{CON}$ cheeses can only be explained by the strong lactic acid fermentation during the first $24 \mathrm{~h}$, leading to a considerable loss of $\mathrm{Ca}$ under the press and in the brine. Thus, the $\mathrm{Ca}$ content of the whey at the time of draining is not always a reliable indicator for the $\mathrm{Ca}$ content found in cheese. The moment and the extent of $\mathrm{pH}$ reduction during cheese making seem to be crucial for the extraction of $\mathrm{Ca}$ from the protein matrix.

The number and the stability of the remaining CCP cross-links, specified as Insol or bound $\mathrm{Ca}$, are affecting the melting properties of cheese. Several studies indicate that bound $\mathrm{Ca}$ is slowly solubilized within the first 2-3 months of cheese ripening due to the breakdown of the protein matrix $[20,29,40]$. In this study, a good correlation between the content of Insol $\mathrm{Ca}$ and the $\mathrm{pH}$ value in the ripe model Raclette cheeses was obtained $(R=0.846)$. The lower the $\mathrm{pH}$ value, the less bound $\mathrm{Ca}$ was detected (Fig. 4). Insol Ca correlated highly significantly with total $\mathrm{Ca}$ in the model Raclette cheeses $(R=0.956)$, which is in agreement with the results obtained in Mozzarella cheese by Metzger and coworkers [31-33]. These findings imply that the adjustment of $\mathrm{pH}$ and total $\mathrm{Ca}$ content during cheese making is essential in order to control the meltability of Raclette cheese. High initial contents of Insol $\mathrm{Ca}$ can be compensated only by an adequate breakdown of the protein matrix. 

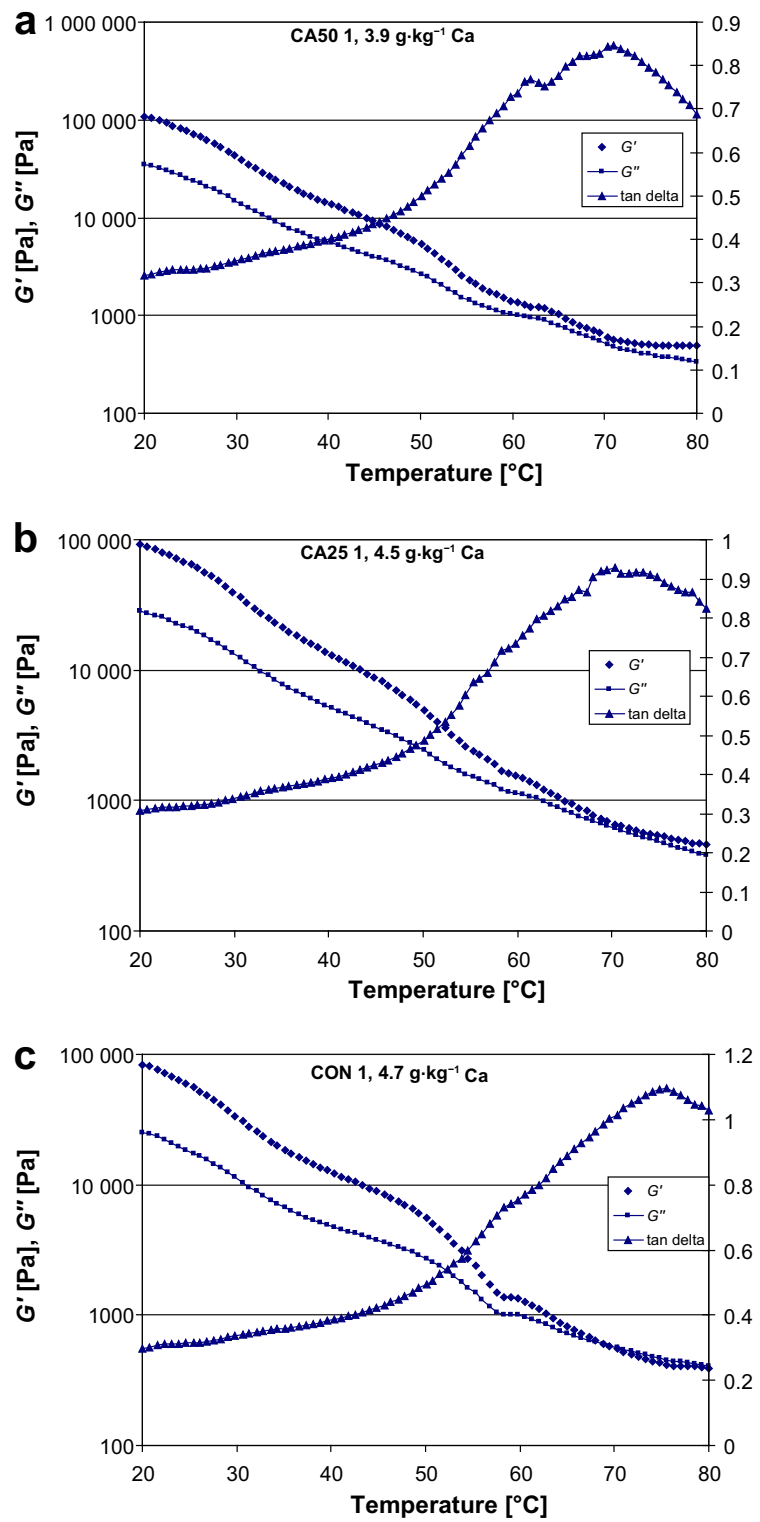

Figure 5. Dynamic small amplitude oscillatory shear test performed with model Raclette cheeses sorted by the Ca content: CA50 with pH 5.20 (a), CA25 with pH 5.25 (b), CON with pH 5.35 (c), LA70 with pH 5.24 (d), LA35 with pH 5.28 (e) and PRE with pH 5.39 (f). $G^{\prime}$, storage modulus; $G^{\prime \prime}$, loss modulus and $\tan (\delta)$, loss tangent as a function of increasing temperature. CON, control Raclette cheese; PRE, pre-ripening; CA50 and CA25, addition of 50 or $25 \mathrm{~g}$ of citric acid, respectively; and LA70 and LA35, addition of 70 or $35 \mathrm{~g}$ of lactic acid, respectively. 

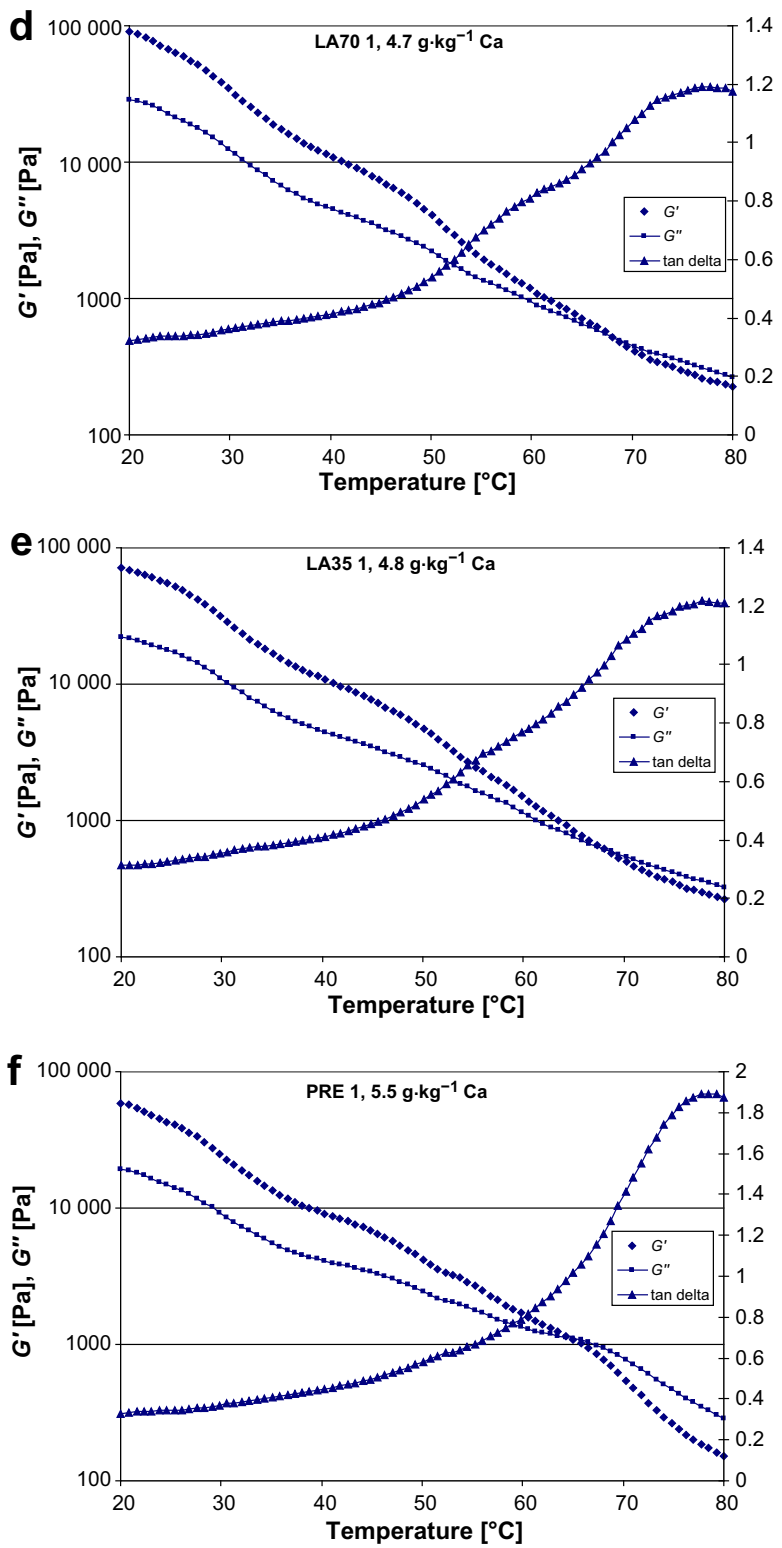

Figure 5. Continued.

\subsection{Rheological analyses}

Figures $5 \mathrm{a}-5 \mathrm{f}$ represent the rheograms of the six Raclette cheese variants from day 1 sorted by ascending $\mathrm{Ca}$ content (data from day 2 were comparable and are not shown). The $G^{\prime}$ and $G^{\prime \prime}$ of all samples decreased as the temperature increased from 20 
to $80{ }^{\circ} \mathrm{C}$. The decrease in $G^{\prime}$ is related to softening of the cheese sample. The LT values increased sharply at about $40-50{ }^{\circ} \mathrm{C}$ and exhibited a maximum ( $\left.\mathrm{LT}_{\max }\right)$ between 65 and $80{ }^{\circ} \mathrm{C}$. This maximum reflects the point of highest bond mobility [29]. Due to the rather low $\mathrm{Ca}$ content of $3.9-5.5 \mathrm{~g} \cdot \mathrm{kg}^{-1}$ in the experimental cheeses, generally lower $\mathrm{LT}_{\text {max }}$ were obtained in comparison to commercial Swiss Raclette cheese (typical $\mathrm{Ca}$ content $6.5 \mathrm{~g} \cdot \mathrm{kg}^{-1}$ with $\mathrm{LT}_{\max }$ values from 2 to 2.5). In contrast to the cheeses of the variants CON, LA70, LA35 and PRE (Figs. 5c-5f), no crossover point was found for CA50 and CA25 cheeses.

The rheological data obtained during heating from 20 to $80{ }^{\circ} \mathrm{C}$ and cooling back to $20{ }^{\circ} \mathrm{C}$ of the six model Raclette cheese variants are summarized in Table V. As no crossover was found for CA50, no SMP and ERP could be determined. Therefore, no complex viscosity at the crossover point (SMP and ERP) could be calculated. Numerically, a value of $80{ }^{\circ} \mathrm{C}$ was assigned for CA50 to SMP and ERP and the corresponding values of the complex viscosity were calculated in order to evaluate statistical values.

A high correlation was found between SMP and ERP $(r=0.98)$. A low ERP is especially desirable for cheese manufacturers because cheese will remain fluid in the consumer's plate over a longer period. In contrast to commercial cheese samples, both SMP and ERP tended to reach high levels in our experiment, especially for CA50 and CA25.

At the beginning of the experiment at $20{ }^{\circ} \mathrm{C}, G^{\prime}$ and $G^{\prime \prime}$ were significantly higher for CA50 as compared to the PRE. The higher $G^{\prime}$ and $G^{\prime \prime}$ values for CA50 indicate a greater "firmness". Shirashoji et al. [41] had found higher $G^{\prime}$ and hardness values for processed cheese with high additions of trisodium citrate. PRE had even lower levels of $G^{\prime}$ and $G^{\prime \prime}$ at $20{ }^{\circ} \mathrm{C}$ at the beginning of the experiment compared to $\mathrm{CON}$. Choi et al. [3] had found similar results where $G^{\prime}$ values at $20{ }^{\circ} \mathrm{C}$ decreased as a result of acidification of milk before manufacture.

A similar phenomenon was observed for $G^{\prime}$ and $G^{\prime \prime}$ at $80^{\circ} \mathrm{C}$. Very high levels were found for CA50 and CA25 compared to $\mathrm{CON}$, again suggesting either additional or stronger bonds inside the casein network for CA50 and CA25. The elastic properties of CA50 were always dominant over the viscous properties even at $80{ }^{\circ} \mathrm{C}$. The structure remained "solid-like" from 20 to $80^{\circ} \mathrm{C}$.

The $\mathrm{LT}_{\max }$ was small for CA25 (1.4) and even below $1(0.9)$ for CA50. The latter cheese had a Ca content of $3.8 \mathrm{~g} \cdot \mathrm{kg}^{-1}$ and a $\mathrm{pH}$ of 5.18. PRE with a Ca content of $5.5 \mathrm{~g} \cdot \mathrm{kg}^{-1}$ and a $\mathrm{pH}$ value of 5.39 clearly showed the highest $\mathrm{LT}_{\max }$ at 1.7. For 92 commercial samples of Swiss Raclette cheese with an average $\mathrm{Ca}$ content of $6.5 \mathrm{~g} \cdot \mathrm{kg}^{-1}$ and a $\mathrm{pH}$ of $5.7, \mathrm{LT}_{\text {max }}$ values between 2.0 and 2.5 were observed in a study by Guggisberg et al. [10]. $\mathrm{LT}_{\max }$ correlated highly negatively $(r=-0.916)$ with $G^{\prime}$ at $20^{\circ} \mathrm{C}$ at the beginning of the experiment (firmness), which is in agreement with the results found by $\mathrm{Lu}$ et al. [25].

In Table VI, the results of the compression test and of the softening (EP) and dropping point (TP) experiment are summarized. The smallest force in the compression test was measured for PRE, whereas $\mathrm{CON}$, LA70 and LA37 showed medium forces and CA50 and CA25 tended towards the highest values. It is assumed that addition of citric acid could have increased the water-binding capacity. The maximum force was found for CA50, the variant with the lowest LT and highest $G^{\prime}$ at 20 and $80{ }^{\circ} \mathrm{C}$. Accordingly, a high correlation between $G^{\prime \prime}$ at $80{ }^{\circ} \mathrm{C}$ and the compression force was found $(r=0.924)$. A significantly higher EP was observed for CA50. Both EP and TP tended towards very high levels for CA50 and CA25. EP was positively correlated with SMP $(r=0.879)$, ERP $(r=0.854)$ and TP $(r=0.838)$. Schluep and Puhan [40] reported that Swiss Raclette 
Table V. Rheological data of model Raclette cheese after 14 weeks of ripening.

\begin{tabular}{|c|c|c|c|c|c|c|c|c|c|c|c|}
\hline $\begin{array}{l}\text { Variants } \\
(n=2)\end{array}$ & $\begin{array}{l}\text { SMP } \\
\left({ }^{\circ} \mathrm{C}\right)\end{array}$ & $\begin{array}{l}\text { ERP } \\
\left({ }^{\circ} \mathrm{C}\right)\end{array}$ & $\begin{array}{c}G^{\prime} \\
\left(20^{\circ} \mathrm{C}\right) \\
(\mathrm{Pa})^{\mathrm{a}}\end{array}$ & $\begin{array}{c}G^{\prime \prime} \\
\left(20^{\circ} \mathrm{C}\right) \\
(\mathrm{Pa})^{\mathrm{a}}\end{array}$ & $\begin{array}{c}G^{\prime} \\
\left(80^{\circ} \mathrm{C}\right) \\
(\mathrm{Pa})\end{array}$ & $\begin{array}{c}G^{\prime \prime} \\
\left(80^{\circ} \mathrm{C}\right) \\
(\mathrm{Pa})\end{array}$ & $\begin{array}{c}\tan \sigma_{\max } \\
\left(20-80^{\circ} \mathrm{C}\right)\end{array}$ & $\begin{array}{c}\eta^{*} \\
(\mathrm{SMP}) \\
(\mathrm{Pa} \cdot \mathrm{s})\end{array}$ & $\begin{array}{c}\tan \sigma_{\max } \\
\left(80-20^{\circ} \mathrm{C}\right)\end{array}$ & $\begin{array}{c}\eta^{*} \\
(\mathrm{ERP}) \\
(\mathrm{Pa} \cdot \mathrm{s})\end{array}$ & $\begin{array}{c}\eta^{*} \\
\left(60^{\circ} \mathrm{C}\right) \\
(\mathrm{Pa} \cdot \mathrm{s})^{\mathrm{b}}\end{array}$ \\
\hline $\mathrm{CON}$ & 66.8 & 59.1 & 76875 & 22960 & 259.3 & 308.3 & 1.4 & 79.2 & 1.4 & 202.0 & 185.2 \\
\hline PRE & 66.0 & 56.9 & 64685 & 20395 & 166.4 & 286.3 & 1.7 & 123.8 & 1.7 & 274.2 & 215.6 \\
\hline CA50 & $80.0^{\mathrm{c}}$ & $80.0^{\mathrm{c}}$ & 108650 & 34365 & 418.4 & 296.5 & 0.9 & 51.3 & 0.9 & 51.3 & 121.2 \\
\hline LA70 & 64.9 & 54.6 & 81000 & 26560 & 157.7 & 228.5 & 1.7 & 95.0 & 1.7 & 213.2 & 140.0 \\
\hline CA25 & 71.9 & 67.8 & 80160 & 24960 & 290.6 & 294.9 & 1.4 & 74.0 & 1.3 & 145.3 & 184.4 \\
\hline LA35 & 66.4 & 56.8 & 70105 & 21985 & 198.3 & 270.2 & 1.5 & 82.9 & 1.5 & 201.3 & 188.8 \\
\hline \multicolumn{12}{|l|}{$P$ value } \\
\hline \multicolumn{12}{|l|}{ ANOVA } \\
\hline Variant & n.s. & 0.069 & * & $*$ & n.s. & n.s. & n.s. & n.s. & n.s. & 0.067 & * \\
\hline Day & n.s. & n.s. & n.s. & n.s. & & & n.s. & n.s. & n.s. & n.s. & n.s. \\
\hline
\end{tabular}

${ }^{*} P \leq 0.05$; n.s., not significant; CON, control Raclette cheese; PRE, pre-ripening; CA50 and CA25, addition of 50 or $25 \mathrm{~g}$ of citric acid, respectively; and LA70 and LA35, addition of 70 or $35 \mathrm{~g}$ of lactic acid, respectively.

${ }^{\text {a }}$ At the beginning of the experiment.

${ }^{\mathrm{b}}$ During cooling.

${ }^{c}$ No SMP and ERP detected. 
Table VI. Compression test, softening and dropping points of model Raclette cheeses after 14 weeks of ripening.

\begin{tabular}{lccccc}
\hline $\begin{array}{l}\text { Variants } \\
(n=2)\end{array}$ & $\begin{array}{c}\text { Maximum force } \\
(\text { compression test })\end{array}$ & $\begin{array}{c}\mathrm{EP} \\
(N)\end{array}$ & $\begin{array}{c}\mathrm{TP} \\
\left({ }^{\circ} \mathrm{C}\right)\end{array}$ & $\begin{array}{c}\text { Difference } \\
\text { TP }- \text { EP }\left({ }^{\circ} \mathrm{C}\right)\end{array}$ & $\begin{array}{c}\text { Index TP } \times \\
\text { difference/100 }\end{array}$ \\
\hline CON & 1.08 & 56.9 & 63.0 & 6.2 & 3.9 \\
PRE & 0.97 & 58.0 & 64.9 & 6.9 & 4.5 \\
CA50 & 1.46 & 62.4 & 70.3 & 7.8 & 5.6 \\
LA70 & 1.00 & 59.1 & 63.7 & 4.6 & 2.9 \\
CA25 & 1.15 & 59.9 & 67.6 & 7.7 & 5.2 \\
LA35 & 1.05 & 56.5 & 64.1 & 7.8 & 5.0 \\
$P$ value ANOVA & & $*$ & & & n.s. \\
Variant & n.s. & n.s. & n.s. & n.s. & n.s. \\
Day & n.s. & n.s. & \\
\hline
\end{tabular}

${ }^{*} P \leq 0.05$; n.s., not significant; CON, control Raclette cheese; PRE, pre-ripening; CA50 and CA25, addition of 50 or $25 \mathrm{~g}$ of citric acid, respectively; and LA70 and LA35, addition of 70 or $35 \mathrm{~g}$ of lactic acid, respectively.

cheese samples with good melting properties meet the following three conditions: (1) TP below $65^{\circ} \mathrm{C}$, (2) difference (TP - EP) below $9{ }^{\circ} \mathrm{C}$ and (3) an index value $(\mathrm{TP} \times$ difference $/ 100)<7$. With the exception of CA50 and CA25 cheeses whose TP values exhibited very high levels, all experimental cheeses fulfilled these three conditions. The results of the compression test and of the EP and TP experiments are in good agreement with the rather distinct behaviour of CA50 and CA25 cheeses observed in the dynamic small amplitude oscillatory shear test. The CA variants especially showed high firmness and atypical melting properties, suggesting a different molecular structure. It is assumed that addition of citric acid dissolved, similar to the manufacture of processed cheese, part of the CCP, and thus increased the waterbinding capacity of the protein matrix, leading to a firmer texture and atypical melting properties of CA50 and CA 25 cheeses. The effects of the different technological and chemical variants on LT are represented in Figure 6. At very low $\mathrm{Ca}$ concentrations $\left(\mathrm{Ca}<4.7 \mathrm{~g} \cdot \mathrm{kg}^{-1}\right)$ and low $\mathrm{pH}$ values
$(<5.25), \mathrm{LT}_{\max }$ remained low and $G^{\prime}$ stayed greater than $G^{\prime \prime}$ indicating a dominance of "solid-like" rheological properties. In other studies [24, 30], the meltability was also reduced (low $\mathrm{LT}_{\max }$ ) at $\mathrm{pH}$ values below 5.0. However, at higher concentrations of $\mathrm{Ca}$ and higher $\mathrm{pH}$, "liquid-like" rheological properties dominated $\left(G^{\prime \prime}>G^{\prime}\right)$. The results of the rheological analyses suggest that both the $\mathrm{Ca}$ content and the $\mathrm{pH}$ value strongly influence the melting properties of Raclette cheese. The influence of low $\mathrm{pH}$ and low $\mathrm{Ca}$ content on LT values could be clearly demonstrated. $\mathrm{LT}_{\max }$ values were positively correlated with total $\mathrm{Ca}(r=0.802)$ and Insol $\mathrm{Ca}(r=0.821)$.

\subsection{Sensory analysis}

The sensory analysis of the melted cheeses on the ceramic plate showed no significant differences between the variants (Tab. VII). There were, nevertheless, some differences that are noteworthy. Although the CA50 cheeses showed the highest values for "firmness" in the rheological tests, they were judged by the panel to be only 


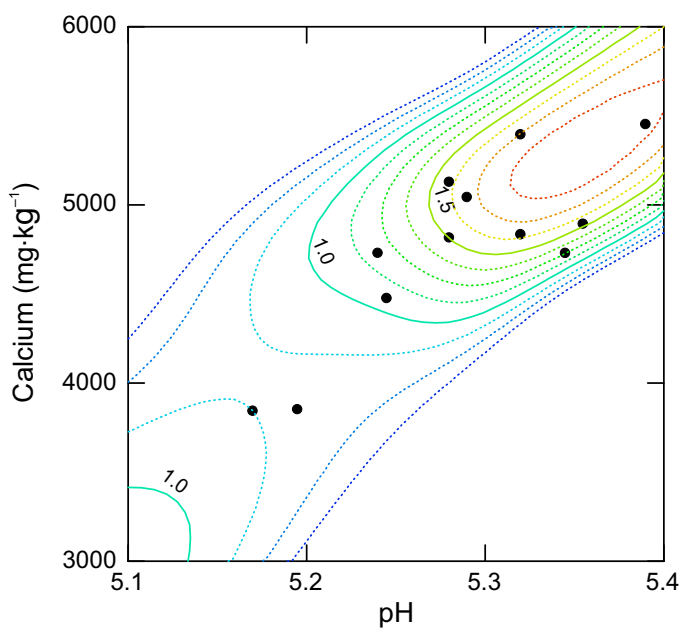

Figure 6. 3-D figure of the influence of $\mathrm{pH}$ and calcium content on loss tangent ( $z$ axis).

slightly gummy. They were also less ropy than the CON and the other variants, but exhibited more fat separation. The LA variants stood out with a positive influence on the flavour. The cheeses were significantly less bitter than the others. Also the aroma qualities were superior.

As previously mentioned, the interactions between total $\mathrm{Ca}$ content, $\mathrm{pH}$ and proteolysis in the ripe cheese are critical parameters that influence the textural properties. In this study, the total Ca content of all cheeses was lower than in the commercial Swiss Raclette cheese. As a consequence, the panel judged the melting properties of the trial cheeses as very good. The melted cheeses were very liquid and had practically no filaments, only the score for the gummy properties was in the medium range. Therefore, further reduction of the cross-linking material in the casein could only lead to an improvement in the gummy properties. As a matter of fact, the gummy attribute of the cheeses correlated to a significant level $(P<0.05)$ negatively with the content of Insol Ca (Fig. 7). The more the $\mathrm{Ca}$ was extracted from the protein matrix, the less gummy the cheeses became from the sensorial point of view $(r=-0.746)$. This was not the case for the ropy and viscous attributes, which correlated only poorly with $\mathrm{Ca}(r=-0.373$ and -0.366 , respectively), which is not surprising since especially the viscous properties depend on the water-binding capacity of the cheese matrix.

\subsection{Final interpretation of melting behaviour}

In cheese, Insol Ca probably exists in the form of CCP attached to the casein matrix or in the form of $\mathrm{Ca}$ bridges between para-casein molecules. Consequently, the para-casein is essentially insoluble and only a small amount of the total moisture in cheese is bound to protein. The effect of citric acid in the model Raclette cheeses was not only due to the reduction of $\mathrm{pH}$ and so to the solubilization of $\mathrm{Ca}$, but also to the sequestration of $\mathrm{Ca}$ as a result of its chelating properties. Since $\mathrm{CCP}$ and $\mathrm{Ca}$ bridges are broken apart, the para-casein gets partially hydrated and becomes soluble. 


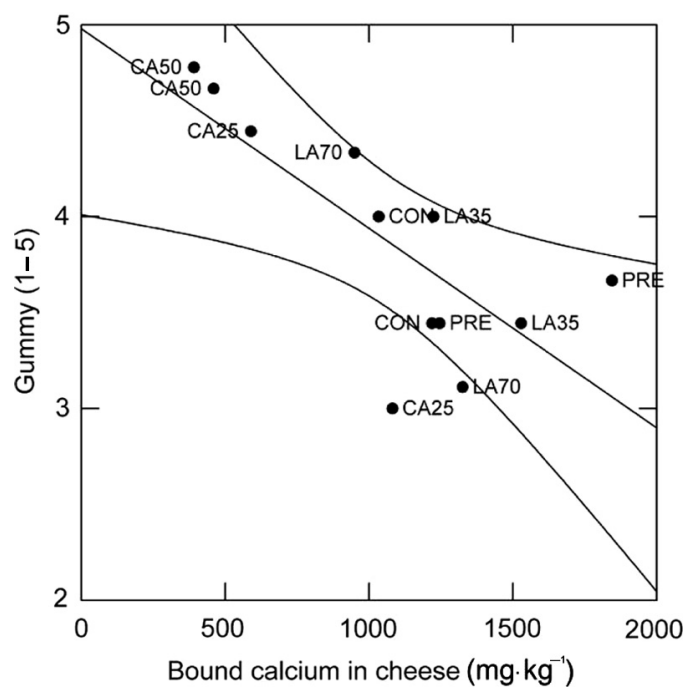

Figure 7. Insoluble calcium in cheese and gummy properties of the melted model Raclette cheeses $(R=-0.746, P \leq 0.05$, confidence interval on the regression line: 0.95$)$. CON, control Raclette cheese; PRE, pre-ripening; CA50 and CA25, addition of 50 or $25 \mathrm{~g}$ of citric acid, respectively; and LA70 and LA35, addition of 70 or $35 \mathrm{~g}$ of lactic acid, respectively.

Table VII. Sensory analysis of the ripe trial Raclette cheeses in melted form.

\begin{tabular}{lccccccccc}
\hline $\begin{array}{l}\text { Variant } \\
(n=2)\end{array}$ & $\begin{array}{c}\text { Fat } \\
\text { separation }\end{array}$ & Viscosity & $\begin{array}{c}\text { Ropy } \\
\text { qualities }\end{array}$ & $\begin{array}{c}\text { Gummy } \\
\text { qualities }\end{array}$ & $\begin{array}{c}\text { Skin } \\
\text { formation }\end{array}$ & Bitterness & Saltiness & $\begin{array}{c}\text { Olfactory } \\
\text { qualities }\end{array}$ & $\begin{array}{c}\text { Aroma } \\
\text { qualities }\end{array}$ \\
\hline CON & 3.39 & 4.11 & 4.17 & 3.72 & 3.83 & 3.44 & 1.78 & 2.83 & 3.00 \\
PRE & 3.17 & 4.17 & 4.28 & 3.56 & 3.67 & 3.61 & 2.17 & 2.67 & 3.17 \\
CA50 & 2.89 & 4.39 & 4.72 & 4.72 & 3.89 & 3.94 & 2.56 & 2.78 & 3.44 \\
LA70 & 3.00 & 4.11 & 3.89 & 3.72 & 3.67 & 4.11 & 3.00 & 2.83 & 3.56 \\
CA25 & 3.11 & 4.22 & 4.61 & 3.72 & 3.61 & 3.78 & 2.33 & 2.83 & 3.61 \\
LA35 & 3.61 & 4.39 & 4.56 & 3.72 & 3.67 & $4.33^{*}$ & 2.00 & 2.50 & 3.72 \\
$P$ value & & & & & & & & & \\
ANOVA & & & & & & $*$ & & & \\
Variant & n.s. & n.s. & n.s. & n.s. & n.s. & $*$ & n.s. & n.s. & n.s. \\
Day & & n.s. & n.s. & & n.s. & n.s. & n.s. & n.s. & n.s. \\
\hline
\end{tabular}

Scale: 5 , slightly; 3 , medium; 1 , highly; ${ }^{*} P \leq 0.05 ;{ }^{* *} P \leq 0.01$; n.s., not significant; ANOVA, analysis of variance; day, day of cheese production; CON, control Raclette cheese; PRE, pre-ripening; CA50 and CA25, addition of 50 or $25 \mathrm{~g}$ of citric acid, respectively; and LA70 and LA35, addition of 70 or $35 \mathrm{~g}$ of lactic acid, respectively.

Subject to the processing conditions, this mechanism is known to take place in the manufacture of processed cheese [11]. With the aid of heat and shear, the emulsifying salts promote the hydration and dispersal of casein, resulting in an increase in the viscosity of the cheese mass. It is suggested that the increased hydration and viscosity 
in the cheeses made with citric acid could explain the atypical rheological behaviour of these cheese samples.

\section{CONCLUSIONS}

The chosen technological and chemical variants were able to induce varying $\mathrm{pH}$ gradients, not only during manufacture but also during ripening, with the resulting varying contents of total and Insol Ca. PRE led to a reduced $\mathrm{pH}$ already before coagulation, but the total $\mathrm{Ca}$ in the cheese was even higher compared to CON. CA25/50 and LA35/70 led to a clear reduction in $\mathrm{pH}$ in the vat during stirring, but only CA50 showed a significant reduction in the total and Insol Ca contents in the ripened cheese underlining that the chelating characteristics of citric acid contributed in an important way to the removal of calcium. The rheological tests described CA50 and CA25 as firmer cheeses that maintained a dominance of "solid-like" properties even at the maximal temperature of $80{ }^{\circ} \mathrm{C}$. Nevertheless, the sensory panel judged the CA25 and CA50 cheeses that showed firmer texture, higher SMP and ERP, lower LT values and an absence of $G^{\prime}-G^{\prime \prime}$ crossover as cheeses with good melting properties. It seems that the sensory panel had a different sensation, irrespective of whether the cheeses showed a typical melting behaviour or not.

Acknowledgements: K. Schafroth is acknowledged for the cheese manufacture in the ALP pilot plant. The authors also thank U. Bütikofer for statistical and scientific assistance.

\section{REFERENCES}

[1] Blumenthal A., Weymuth H., Hansen W., Käse für Raclette: idealer Tropfpunkt bei $65^{\circ} \mathrm{C}$, Die Fliess- und Tropfpunkte für Raclette-Käse, Schweiz. Milchztg. 102 (1976) 391-395.
[2] Chevanan N., Muthukumarappan K., Effect of calcium and phosphorus, residual lactose, and salt-to-moisture ratio on the melting characteristics and hardness of cheddar cheese during ripening, J. Food Sci. 72 (2007) E168-E176.

[3] Choi J., Horne D.S., Johnson M.E., Lucey J.A., Effects of the concentration of insoluble calcium phosphate associated with casein micelles on the functionality of directly acidified cheese, J. Dairy Sci. 91 (2008) 513-522.

[4] Collomb M., Spahni M., Steiger G., Dosage de la teneur en azote selon Kjeldahl de produits laitiers et de certaines de leurs fractions azotées à l'aide d'un système automatisé, Trav. chim. alim. hyg. 81 (1990) 499-509.

[5] Eberhard P., Moor U., Rüegg M., Zusammensetzung und physikalische Eigenschaften gut und ungenügend schmelzender Raclettekäse. I. Raclettekäse aus pasteurisierter Milch [Composition and physical properties of Raclette cheese with good and unsatisfactory melting characteristics. I. Raclette cheese from pasteurized milk], Schweiz. Milchwirtschaftliche Forsch. 17 (1988) 3-8.

[6] Eberhard P., Moor U., Rüegg M., Zusammensetzung und physikalische Eigenschaften gut und ungenügend schmelzender Raclettekäse. II. Walliser Rohmilch-Raclettekäse [Composition and physical properties of Raclette cheeses with good and unsatisfactory melting characteristics. II. Walliser Raclette cheese], Schweiz. Milchwirtschaftliche Forsch. 17 (1988) 47-52.

[7] Eberhard P., Moor U., Rüegg M., Flückiger E., Objektive Erfassung des Erweichungsund Tropfpunktes von Raclettekäse, Schweiz. Milchwirtschaftliche Forsch. 15 (1986) 9396.

[8] Fröhlich-Wyder M.T., Bütikofer U., Guggisberg D., Wechsler D., Raclettekäse: weniger Kalzium für bessere Schmelzeigenschaften, Agrarforschung 14 (2007) 10-15.

[9] Fröhlich-Wyder M.T., Bütikofer U., Guggisberg D., Wechsler D., Kalzium in Raclettekäse: Bedeutung von $\mathrm{pH}-$ Wert und Komplexbildung, Agrarforschung 14 (2007) 56-61.

[10] Guggisberg D., Bütikofer U., Albrecht B., Melting and solidification characteristics of Swiss Raclette cheese measured by small amplitude oscillatory shear measurements, J. Texture Stud. 38 (2007) 297-323. 
[11] Guinee T.P., Caric M., Kalab M., Pasteurized Processed Cheese and Substitute/Imitation Cheese Products, in: Fox P.F., McSweeney P.L.H., Cogan T.M., Guinee T.P. (Eds.), Cheese: Chemistry, Physics and Microbiology, Major Cheese Groups, Elsevier Academic Press, Amsterdam, The Netherlands, 2004, pp. 349-394.

[12] Guinee T.P., Feeney E.P., Auty M.A.E., Fox P.F., Effect of $\mathrm{pH}$ and calcium concentration on some textural and functional properties of Mozzarella cheese, J. Dairy Sci. 85 (2002) 1655-1669.

[13] Gunasekaran S., Ak M.M., Cheese Rheology and Texture, CRC Press, Boca Raton FL; London, UK; New York, NY; Washington, DC, 2003.

[14] IDF Standard 4, Cheese and Processed Cheese - Determination of the Total Solids Content (Reference Method), International Dairy Federation, Brussels, Belgium, 2004.

[15] IDF Standard 88, Cheese and Processed Cheese Products - Determination of Chloride Content - Potentiometric Titration Method, International Dairy Federation, Brussels, Belgium, 2006.

[16] IDF Standard 119, Milk and Milk Products Determination of Calcium, Sodium, Potassium and Magnesium Contents - Atomic Absorption Spectrometric Method, International Dairy Federation, Brussels, Belgium, 2007.

[17] IDF Standard 25, Processed Cheese Products - Determination of Nitrogen Content and Crude Protein Calculation - Kjeldahl Method, International Dairy Federation, Brussels, Belgium, 2008.

[18] ISO Standard 3432, Cheese - Determination of Fat Content - Butyrometer for Van Gulik Method, International Organization for Standardization, Geneva, Switzerland, 1975.

[19] ISO Standard 3433, Cheese - Determination of Fat Content - Van Gulik Method, International Organization for Standardization, Geneva, Switzerland, 1975.

[20] Johnson M.E., Lucey J.A., Calcium: a key factor in controlling cheese functionality, Aust. J. Dairy Technol. 61 (2006) 147-153.

[21] Joshi N.S., Muthukumarappan K., Dave R.I., Role of soluble and colloidal calcium contents on functionality of salted and unsalted partskim Mozzarella cheese, Aust. J. Dairy Technol. 57 (2002) 203-210.

[22] Joshi N.S., Muthukumarappan K., Dave R.I., Understanding the role of calcium in functionality of part skim Mozzarella cheese, J. Dairy Sci. 86 (2003) 1918-1926.

[23] Lawrence R.C., Creamer L.K., Gilles J., Texture development during cheese ripening, J. Dairy Sci. 70 (1987) 1748-1760.

[24] Lee M.R., Johnson M.E., Lucey J.A., Impact of modifications in acid development on the insoluble calcium content and rheological properties of Cheddar cheese, J. Dairy Sci. 88 (2005) 3798-3809.

[25] Lu Y., Shirashoji N., Lucey J.A., Rheological, textural and melting properties of commercial samples of some of the different types of pasteurized processed cheese, Int. J. Dairy Technol. (2007) 74-80.

[26] Lucey J.A., Formation and physical properties of milk protein gels, J. Dairy Sci. 85 (2002) 281-294.

[27] Lucey J.A., Fox P.F., Importance of calcium and phosphate in cheese manufacture: a review, J. Dairy Sci. 76 (1993) 1714-1724.

[28] Lucey J.A., Johnson M.E., Horne D.S., Invited review: perspectives on the basis of the rheology and texture properties of cheese, J. Dairy Sci. 86 (2003) 2725-2743.

[29] Lucey J.A., Mishra R., Hassan A., Johnson M.E., Rheological and calcium equilibrium changes during the ripening of Cheddar cheese, Int. Dairy J. 15 (2005) 645-653.

[30] McMahon D.J., Paulson B., Oberg C.J., Influence of calcium, $\mathrm{pH}$, and moisture on protein matrix structure and functionality in direct-acidified nonfat Mozzarella cheese, J. Dairy Sci. 88 (2005) 3754-3763.

[31] Metzger L.E., Barbano D.M., Kindstedt P.S., Effect of milk preacidification on low fat Mozzarella cheese: III. Post-melt chewiness and whiteness, J. Dairy Sci. 84 (2001) 13571366.

[32] Metzger L.E., Barbano D.M., Kindstedt P.S., Guo M.R., Effect of milk preacidification on low fat Mozzarella cheese: II. Chemical and functional properties during storage, J. Dairy Sci. 84 (2001) 1348-1356.

[33] Metzger L.E., Barbano D.M., Rudan M.A., Kindstedt P.S., Effect of milk preacidification on low fat Mozzarella cheese. I. Composition and yield, J. Dairy Sci. 83 (2000) 648658.

[34] Mizuno R., Lucey J.A., Effects of emulsifying salts on the turbidity and calciumphosphate-protein interactions in casein micelles, J. Dairy Sci. 88 (2005) 3070-3078. 
[35] Mizuno R., Lucey J.A., Effects of two types of emulsifying salts on the functionality of nonfat pasta filata cheese, J. Dairy Sci. 88 (2005) 3411-3425.

[36] Mulder H., Walstra P., The Milk Fat Globule: Emulsion Science as Applied to Milk Products and Comparable Foods, Universities Press, Belfast, Northern Ireland, 1974.

[37] O’Mahony J.A., McSweeney P.L.H., Lucey J.A., A model system for studying the effects of colloidal calcium phosphate concentration on the rheological properties of cheddar cheese, J. Dairy Sci. 89 (2006) 892-904.

[38] Rüegg M., Schmelzeigenschaften von Käse, Milchwirtschaftliche Berichte Wolfpassing Rotholz 101 (1989) 242-246.

[39] Rüegg M., Eberhard P., Popplewell L.M., Peleg M., Melting properties of cheese, Bulletin FIL-IDF 268 (1991) 36-43.

[40] Schluep K., Puhan Z., Charakterisierung der Schmelzbarkeit von Raclettekäse mit definierbaren Parametern, Schweiz. Milchwirtschaftliche Forsch. 16 (1987) 61-67.
[41] Shirashoji N., Jaeggi J.J., Lucey J.A., Effect of trisodium citrate concentration and cooking time on the physicochemical properties of pasteurized process cheese, J. Dairy Sci. 89 (2006) 15-28.

[42] Stenz B., Hoglmeier A., Fischer U., Rock S., Kulozik U., Comparison of the melting properties of cheese by means of meltability tests and rheological measurements, Milchwissenschaft - Milk Sci. Int. 61 (2006) 304-307.

[43] Swiss Food Manual 5/02, Bundesamt für Gesundheit, Bern, Switzerland, 2000.

[44] Udayarajan C.T., Lucey J.A., Horne D.S., Use of Fourier transform mechanical spectroscopy to study the melting behavior of cheese, J. Texture Stud. 36 (2005) 489-515.

[45] Upreti P., Metzger L.E., Influence of calcium and phosphorus, lactose, and salt-to-moisture ratio on cheddar cheese quality: $\mathrm{pH}$ changes during ripening, J. Dairy Sci. 90 (2007) 1-12. 